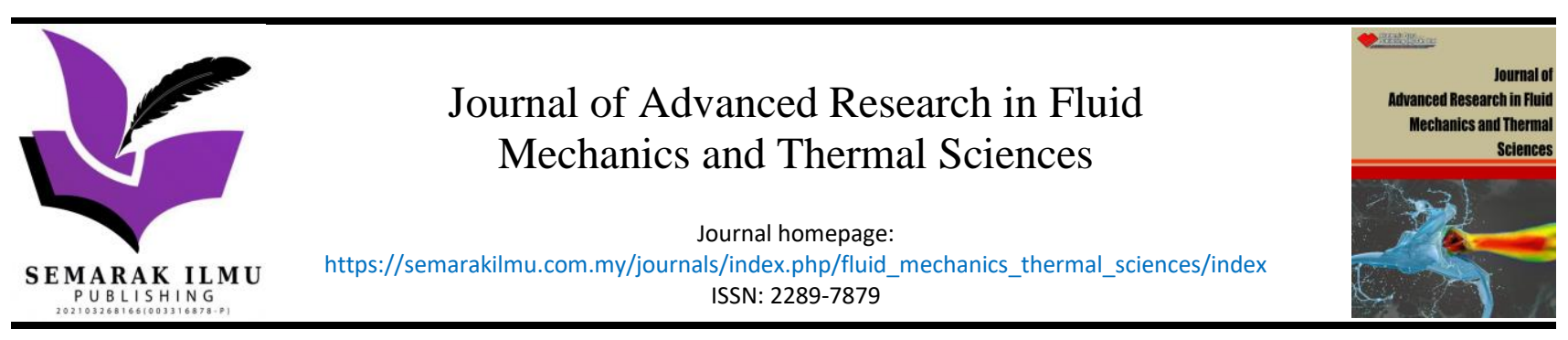

\title{
Techno-Economic Evaluations: An Innovative of Hydraulic Reaction Turbine for Pico-Hydro Generation System
}

\author{
Nurul Ashikin Mohd Rais ${ }^{1}$, Mohd Farriz Basar ${ }^{1,}{ }^{*}$, Shamsul Fakhar Abd Gani ${ }^{1}$, Wan Azani Mustafa ${ }^{2}$ \\ 1 Faculty of Electrical and Electronic Engineering Technology, Universiti Teknikal Malaysia Melaka, Hang Tuah Jaya, 76100 Durian Tunggal, \\ Melaka, Malaysia \\ 2 Faculty of Electrical Engineering Technology, Universiti Malaysia Perlis (UniMAP), Pauh Putra Campus, Arau, 02600, Malaysia
}

\section{ARTICLE INFO}

\section{Article history:}

Received 18 August 2021

Received in revised form 27 November 2021

Accepted 9 December 2021

Available online 27 December 2021

\section{Keywords:}

Low-head; low-flow; techno-economic; pico-hydro; CPT; SRT

\section{ABSTRACT}

\begin{abstract}
The primary goal of this paper is to evaluate an innovative Z-Blade turbine technology and its potential implications for production costs and manufacturing techniques. From literatures, conventional pico-hydro technologies with a capability of less than $5 \mathrm{~kW}$ are getting more and more attention as good alternatives to environmentally friendly power generation, but there are more expensive and complex for small power generation and small domestic consumer level. Therefore, a Z-Blade reaction turbine technical and environmental processes as well as financial research are described indepth. The methods for a Z-blade turbine design and implementation are described here, and also the material using for the Z-Blade turbine is a grey PVC pipe. Moreover, empirical description, designation, costing, and correlation are employed in the process of critically analysing the simple reaction water turbine novels. Also in this article, the manufacture of the Split Reaction Turbine (SRT) and Cross Pipe Turbine (CPT) was re-evaluated to take into consideration the technological and economic factors as well as the difficulties of both turbines. In the meantime, low-head, low-flow water resources used to examine additional features of Z-Blade. Theoretically, such a platform for hydro production is cost - effective and has a simplistic design methodology with a total cost of USD76 that equates to $7.6 \%$ of the overall installation cost and worthy of output up to $115 \mathrm{~W}$ of mechanical energy.
\end{abstract}

\section{Overview}

At this moment, "pico-hydro power generation system" refers to a form of clean power generation so that utilizes small-scale water energy to generate electricity with capabilities of only about $5 \mathrm{~kW}$ [1-3]. The last decade, there has been far less work done on pico-hydro in comparison to additional renewable power sources, including such wind, PV, and the marine energy sector [4]. The major reason for this is because of the lack of existing pico-hydro innovations and also the concern over the expense of production. Even with the enormous potential to consistently create power,

\footnotetext{
* Corresponding author.

E-mail address: mfarriz@utem.edu.my
}

https://doi.org/10.37934/arfmts.90.2.919 
given an equal consistent flow of running water, there are currently no commercial pico-hydro technologies in existence [5-7].

The complexity of designs required for water turbines, it is among the biggest issues challenged by scholars in the mechanism of pico-hydro production [8]. Besides, the system has to be produced using high-tech with extremely competent labourers' machining, which increases the overall production cost and thus lowers the system's overall cost-effectiveness. In addition, the vast majority of pico-hydro development is non-standard and could be applied to all kinds of locations, such as a custom-designed and equipped system [9-11]. There is also the consideration that once the turbine is installed, updating the design scheme could be quite costly [12]. As such, alternative economic and cost-effective options are required to be reduced the price while also promoting Pico-hydropower production as a widely known power source for rural residents [13-15].

Costly and complicated for small energy production and limited household consumer-level use, previous studies believe that the following minimal low head and little mass flow rate hydro rotors are costly and time-consuming [16-18]. The difficulties posed by this problem are taken into consideration, it becomes apparent that a cheap and compact hydro turbine with a low head needs to be provided to enable the utilization of available hydropower such as creeks and small rivers [19]. Impulse and reaction turbines are presently the only two types of water turbines [20]. The existing machine available, while somewhat better suited for minimal water head level and at minimal rate of water sources, is still commercialized only for higher-head and higher-flow water sources. The Split Reaction Turbine (SRT) [8] is the nearest approximation of this kind, however, it is only applicable to hydro sites at a slender head, and with minimal mass flow rate hydro areas. To further improve on the Cross Pipe Turbine (CPT) [5-7], that has been invented previous, the SRT has been developed as a replacement. Table 1 equates the design and materials of SRT, CPT, and Z-blade turbines.

\section{Table 1}

The three simple reaction turbines are as follows $[5,10]$

\begin{tabular}{|c|c|c|c|}
\hline $\begin{array}{l}\text { Water type } \\
\text { turbine }\end{array}$ & SRT & CPT & Z-Blade \\
\hline Substances & PVC grey piping & Metal rod galvanised & PVC grey piping \\
\hline $\begin{array}{l}\text { Design } \\
\text { Requirement }\end{array}$ & $\begin{array}{l}\text { Placing the centre plate } \\
\text { at the top and the base } \\
\text { surface at the lower } \\
\text { part to form the exit } \\
\text { nozzles. }\end{array}$ & $\begin{array}{l}\text { A cross-shaped pipe connects the } \\
\text { two mounting kit forearm at the } \\
\text { centre. To redirect the flow, every } \\
\text { other arm holds a decrease } \\
\text { forearm to rotate the turbine in the } \\
\text { perpendicular direction. At the exit, } \\
\text { both elbows have steady flow jet } \\
\text { nozzles connected. }\end{array}$ & $\begin{array}{l}\text { There are four critical turbine } \\
\text { parts, all of which can be made } \\
\text { using different tubing and fittings: } \\
\text { (a) The T-joint pipe in the middle, } \\
\text { (b) the PVC adapter fittings with a } \\
\text { male threaded end and a female } \\
\text { threaded end, (c) a } 90^{\circ} \text { PVC } \\
\text { elbow, and (d) a cap that is made } \\
\text { from PVC pipe. }\end{array}$ \\
\hline $\begin{array}{l}\text { Critical } \\
\text { part/process }\end{array}$ & $\begin{array}{l}\text { A seal placed on the V- } \\
\text { ring of the lip and an } \\
\text { adhesion process that } \\
\text { utilises the splintered } \\
\text { pipe with the bottom } \\
\text { cover plate }\end{array}$ & V-ring lip seal & Turbine coupling \\
\hline $\begin{array}{l}\text { Fabrication } \\
\text { difficulty }\end{array}$ & $\begin{array}{l}\text { Tough } \\
\text { (a minimum of } 6 \text { hours) }\end{array}$ & $\begin{array}{l}\text { Intermediate } \\
\text { (a minimum } 4 \text { of hours) }\end{array}$ & $\begin{array}{l}\text { Minimal } \\
\text { (a minimum of } 2.5 \text { hours) }\end{array}$ \\
\hline $\begin{array}{l}\text { Services \& } \\
\text { Cleaning }\end{array}$ & Complicated & Average & Simple \\
\hline Design Life & $\begin{array}{l}\text { Friction loss is low and } \\
\text { corrosion-resistant. }\end{array}$ & $\begin{array}{l}\text { Friction loss at a moderate level, } \\
\text { but ability to withstand high } \\
\text { pressure. }\end{array}$ & $\begin{array}{l}\text { Fiction loss is very low and } \\
\text { extremely durable. }\end{array}$ \\
\hline Inspired by & Savonius wind turbine & Lawn sprinkler & Lawn sprinkler \\
\hline
\end{tabular}


Newly improved, simple operation, and affordable to manufacture, an outward-flow reaction turbine has been formulated to work out some of the additional costs and glitches with the existing pico-hydro rotor architecture. Therefore, the Z-Blade rotor was introduced. Such a turbine is built for small-scale water use (less than $3 \mathrm{~m}$ head, $2.5 \mathrm{~L} / \mathrm{sec}$ flow). This reconfigured and updated edition of the CPT and SRT has taken inspiration from the sprinkler design concept. Because of its reliable and inexpensive structure, that also uses only regular standard PVC pipe and plumbing pipes, the fabrication process is less intricate.

Next, discuss how an innovative Z-Blade reaction water rotor works using the identical concept as a previous concept that in pico-hydro spectrum for minimal-head, low mass flow rate implementations. Likened to the previous constraints, the Z-Blade rotor is notable for its advancement. This Z-Blade turbine construction and design process uses locally sourced materials. These design and procedural approaches to solving the issues of the expense and relevance of the device to small water sources takes into consideration the problem areas. Non-interference speed of rotation is derived because of the lack of jet interference in the Z-Blade rotor. At long last, the test unit's performance is quantified and assessed.

\section{Framework of the Z-Blade Water Turbine}

As in 18th era, a research [5-9] on water reaction turbines implemented the categorization of reaction turbine are divided into seven (7) categories, and the latest was invented in 2009 . This research article, is discussed the newest edition called the Z-Blade, where it created in 2014 . This innovative turbine is generally regarded as having the simplest geometric design and the most straightforward fabrication process and is thus cited as being in comparison to the other seven turbines listed above. The turbine has the appearance of a lawn sprinkler, however, it does in fact operate with low water levels as well as little water. The turbine in this example is cheap, easy to use, and can be installed and maintained by the end user.

Standard galvanized tube of grey PVC Class D pipe iron (GI), was replaced by differences that have been implemented in relation to the CPT, which is easily modifiable. Figure 1 illustrates the concept perfectly of Z-Blade turbines, were created by utilizing normal PVC piping fixtures with an insignificant width of $25 \mathrm{~mm}(1 ")$. The turbine has four critical rotor sections: (a) a T-joint piping unit placed in middle, (b) double $90^{\circ}$ PVC elbow units, (c) two PVC end cap units, and (d) two PVC pipe units of various lengths. Drilling the PVC end cap forms the inlet water jet nozzle. When a spray nozzle is fixed to the exit of an elbow, the results can be disastrous in the CPT. Unlike the CPT and SRT, the Z-blade turbine's nozzle exit area has no set dimensions. To control the nozzle exit area, all that is required is to make adjustments and modifications to the nozzle exit area. It is very easy to locate the different components, including the male adapter fitting, PVC piping, and PVC $90^{\circ}$ elbow, as well as the end cap, at local hardware stores. 


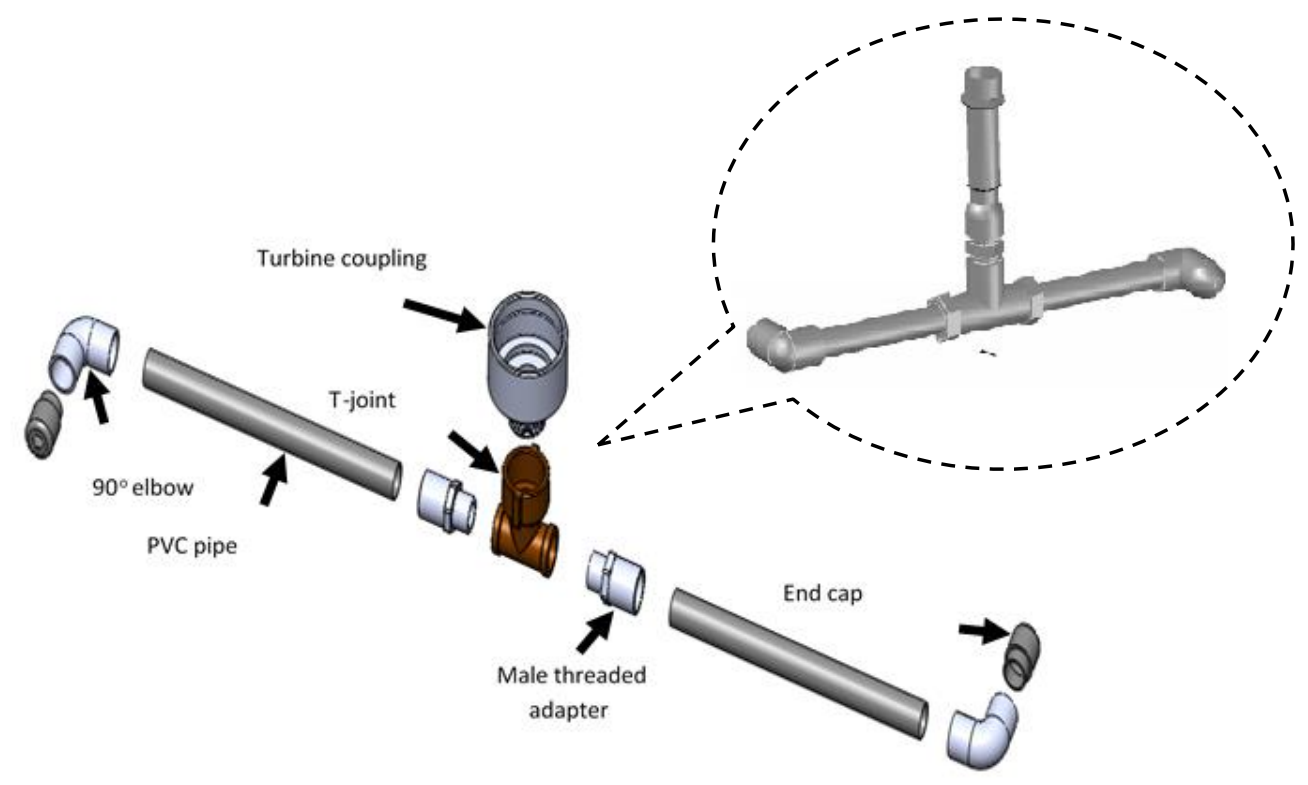

Fig. 1. Design of Z-Blade turbine

\section{The Enhancement of Costing and Water Supply}

In accordance with [5,6], Table 2 depicts a rate estimation of manufacture for a particular element with various categories of a pico-hydro rotor, each of which has a different reaction time. In conclusion, the actual price for a Z-Blade rotor is nearly $50 \%$ lower than the total price of manufacture for a SRT or CPT turbine. It is determined that the turbines of three different designs are comparable as far as equipment costs is concerned (only for turbine parts) and production costs.

As shown in Table 2, the overall cost of raw product and manufacturing of the SRT and CPT between of USD150 for both devices. The Z-Blade rotor, on the other hand, was discovered to be more cost-effective, at only USD75 per turbine, at an overall price is much less than half the CPT and $\mathrm{SRT}$. Aside from that, the manufacturing duration necessary to design the Z-blade turbine is roughly $2 \frac{1}{2}$ hours labour, which is a significant reduction in comparison to the manufacturing period needed to build the SRT (six hours) and CPT (four hours). In the case of the SRT, labour costs account for 63 percent of the total expense, that also adds up to USD96. For CPT, on the other hand, material costs account for $58 \%$ of the overall cost, or USD87 per unit of production. The overall expenses of labour and materials for the rotor, on the other hand, are nearly equal, as illustrated in the Table 2.

Due to its uncomplicated geometrical design, the Z-Blade structure presented in this study necessitates the use of a simple fabrication technique. Pipe fitting and turbine technology aren't complicated enough to warrant the use of advanced or specialised skills in the assembly of parts. Just a person is needed to construct the instrument, which takes $2 \frac{1}{2}$ hours in total to complete. The majority of this time has been consumed on water coupling preparatory work ( 2 hours), installation and adjusting, and decontamination ( $1 / 2$ hours). In the meantime, the time required for the installation and harmonizing of the CPT is $1 \frac{1}{2}$ hours longer than the time required for the Z-Blade assembly. 


\section{Table 2}

Estimate of three different types of water turbine

\begin{tabular}{|c|c|c|c|c|c|}
\hline $\begin{array}{l}\text { Water Type } \\
\text { Turbine }\end{array}$ & Rotor Components & $\begin{array}{l}\text { Substances } \\
\text { Cost (USD) }\end{array}$ & $\begin{array}{l}\text { Manufacturing } \\
\text { Times }(\$ 16 / \mathrm{h})\end{array}$ & $\begin{array}{l}\text { Manufacturing } \\
\text { Rate (USD) }\end{array}$ & $\begin{array}{l}\text { Sum } \\
\text { (USD) }\end{array}$ \\
\hline \multirow[t]{7}{*}{ SRT $[7,8]$} & $\begin{array}{l}\text { PVC piping }(25 \mathrm{~cm} \times 15 \\
\mathrm{cm})\end{array}$ & 8 & 0.5 & 8 & 16 \\
\hline & $\begin{array}{l}\text { PVC cylinders } \varnothing 30 \mathrm{~cm} \mathrm{x} \\
0.4 \mathrm{~cm}:(\text { Vol. \#2) }\end{array}$ & 8 & 0.5 & 8 & 16 \\
\hline & $\begin{array}{l}\text { Bolted transmitting } \\
\text { connecter }\end{array}$ & 24 & Non & Non & 24 \\
\hline & Cast iron access dork & 12 & 3 & 48 & 60 \\
\hline & $\begin{array}{l}\text { Vinyl rubber cylinder } \\
\text { stopper }\end{array}$ & 5 & Non & Non & 5 \\
\hline & $\begin{array}{l}\text { Integrating as well as } \\
\text { adjusting }\end{array}$ & Non & 2 & 32 & 32 \\
\hline & Sum & 57 & 6 & 96 & 153 \\
\hline \multirow[t]{8}{*}{ CPT $[7,8]$} & $3 "$ travers & 28 & Non & Non & 28 \\
\hline & $\begin{array}{l}3 " x \text { × } 2 \text { reduce forearms } \\
(\text { Vol. \#2) }\end{array}$ & 5.5 each & Non & Non & 11 \\
\hline & $\begin{array}{l}\text { 3" connector fitting (Vol. } \\
\# 2 \text { ) }\end{array}$ & 8 each & Non & Non & 16 \\
\hline & $\begin{array}{l}\varnothing 1.5 \mathrm{~cm} \text { compact stream } \\
\text { piston (Vol. \#2) }\end{array}$ & 9.5 each & Non & Non & 19 \\
\hline & Transmitting connector & 8 & 2 & 32 & 40 \\
\hline & V ring stopper & 5 & Non & Non & 5 \\
\hline & $\begin{array}{l}\text { Integrating as well as } \\
\text { adjusting }\end{array}$ & Non & 2 & 32 & 32 \\
\hline & Sum & 87 & 4 & 64 & 151 \\
\hline \multirow{9}{*}{$\begin{array}{l}\text { Z-Blade } \\
\text { rotor }\end{array}$} & Connector (Vol. \#1) & 30 & 2.0 & 32 & 52 \\
\hline & $\begin{array}{l}\text { * SKF radial shaft seal } \\
30 \times 62 \times 10 \text { (Vol. \#1) } \\
\text { * Cylindrical roller bearing } \\
30 \times 62 \times 16(\text { Vol. \#1) } \\
\text { * C-clip (Vol. \#2) } \\
\text { * Cove piping: OD 3"(Vol. } \\
\text { \#1) } \\
\text { * Pairing casing (Vol. \#1) }\end{array}$ & & & & \\
\hline & T-joint piping (Vol. \#1) & 1.5 & Non & Non & 1.5 \\
\hline & 1" PVC forearm (Vol. \#2) & 0.5/piece & Non & Non & 1 \\
\hline & 1" PVC end cap (Vol. \#2) & 0.5/piece & Non & Non & 1 \\
\hline & $\begin{array}{l}\text { 1" male woven coupling } \\
\text { (Vol. \#2) }\end{array}$ & 0.5/piece & Non & Non & 1 \\
\hline & 1" PVC piping (1 meter) & $1.5 /$ meter & Non & Non & 1.5 \\
\hline & $\begin{array}{l}\text { Integrating as well as } \\
\text { adjusting }\end{array}$ & Non & 0.5 & 8 & 8 \\
\hline & Sum & 36 & 2.5 & 40 & 76 \\
\hline
\end{tabular}

\section{Experimentation with Enhancement of the Water Head}

A further disadvantage that has been observed in both SRT and CPT is the manner in which the rotors are connected to the power generation system. Unless the direct connector coupling is synchronised with the throttle of the generator, the effectiveness of the turbine will be significantly reduced. It generates a lot of friction, which eventually causes the coupling to seize up, which tends to cause the rotor to rotate with a skew. The socket jointing shown in Figure 2 is used to avoid the 
connection method, which is mainly important at the turbine coupling, from experiencing excessive downward frictional force. Most of the time, the top of the water's surface, the volume of the movable rotor, and the force of gravity all combine to effect the centrifugal acceleration and produce a significant amount of friction between the direct connection between both the turbine and the throttle of the electric motor. Slot jointing is a technique used to improve the performance of systems. As a result, joint slot allows the blade rotor to remain detached in the socket rather than being firmly connected to the shaft generator, that further enhances implementation and redevelopment work in turn.

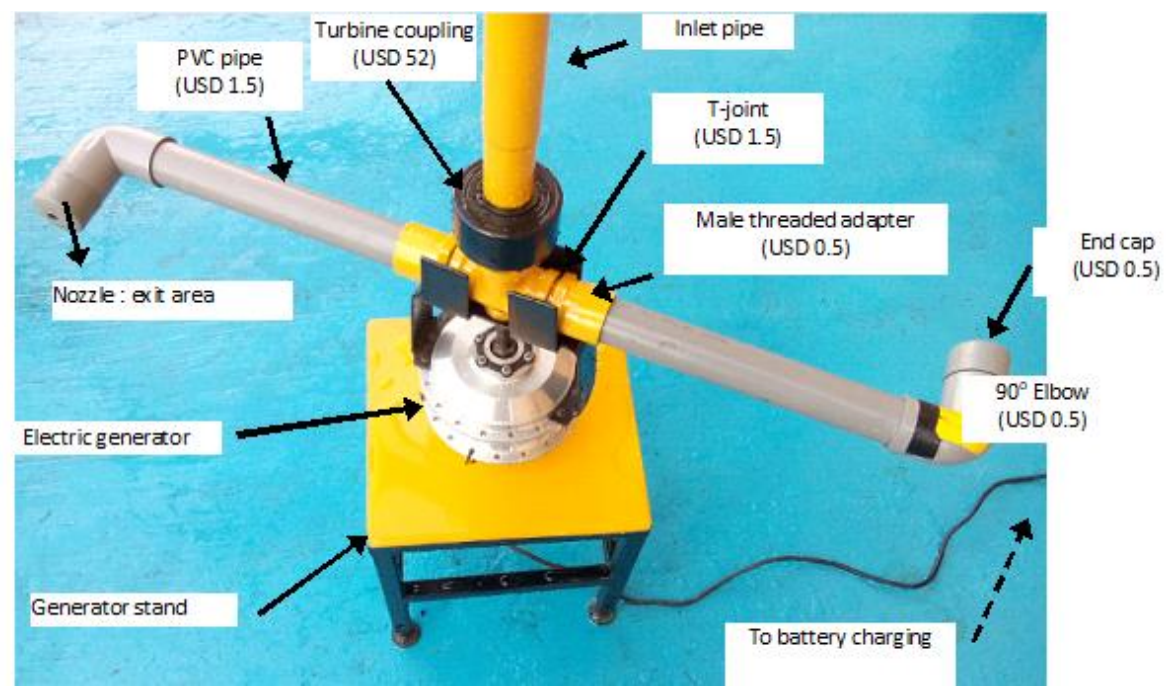

Fig. 2. Material cost of a Z-Blade turbine

Figure 3 shows a test rig that was constructed in order to display the research implementation of Z-Blade rotor. The 350-litre polypropylene water tank was used to preserve the fluids. To rise the efficiency of the water use, a 6-meter-high metal was supported the water reservoir conceptual model tower, and it was set up to deliver water into the Z-Blade turbine from the top. This water test rig can generate up to $5 \mathrm{~m}$ of water and supply up to $3 \mathrm{~L} /$ second of water flow. Furthermore, seeing as clogged up by buoyant waste is a big issue for hydro-kinetic turbines in many rivers and streams [11], To keep large particles or wreckage from trying to enter the turbine, a filtering system was developed in the test platform.

Experimental work variables include the dimensions of the width size of PVC piping, $\mathrm{S}$, the fluid pressure, $\mathrm{H}$, together with rotor radius, $\mathrm{R}$. In this water had a static water head of between 3 and 5 metres. Using two diameters of PVC pipe, one measuring $\varnothing 25 \mathrm{MM}(1 ")$ and the other measuring $\varnothing 15 \mathrm{MM}\left(1 / 2^{\prime \prime}\right)$, the rotor blade's diameter was fluctuated from $0.3 \mathrm{~m}$ to $2.0 \mathrm{~m}$. 


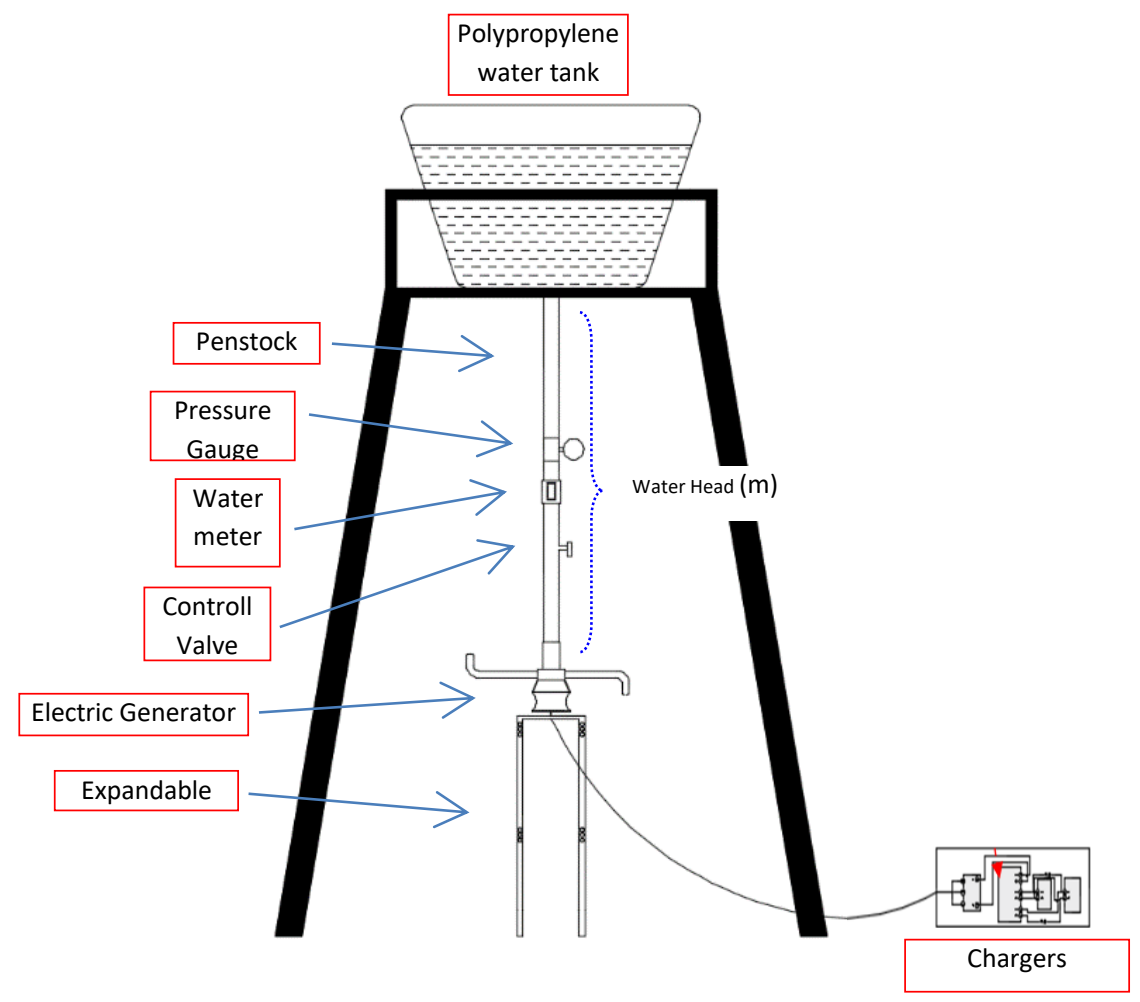

Fig. 3. Water test rig of Z-Blade turbine

The mathematical model and equations presented by [5-9] are explored in accordance with the theory of Bernoulli's. To describe ability of the viscous fluid water condition, the Z-Blade reactant hydraulic motor in order to generates electricity, the quantitative method is adopted to the turbine. When no frictional losses are present, these equations give an ideal case

$U=R \omega$

$V_{a}=V_{r}-U$

Whenever the rotor is not static, $\omega \neq 0$. The centrifugal head, $H_{C}$ become

$$
H_{c}=\frac{U^{2}}{2 g}=\frac{R^{2} \omega^{2}}{2 g}
$$

An amount of water flow $(\dot{m})$ that can be quantified by means of

$$
\dot{m}=\rho A \sqrt{2 g H+R^{2} \omega^{2}}
$$

The angular speed of the rotor can be calculated by rewriting Eq. (4) 
$\omega=\sqrt{\frac{\left(\frac{\dot{m}}{\rho A}\right)^{2}-2 g H}{R^{2}}}$

Then, the equation of torque can be calculated as

$T=\dot{m} V_{a} R$

Therefore, the mechanical output power $\dot{W}$ produce by the turbine

$\dot{W}=T \omega$

\section{Outcome Operating Parameters}

The study outcomes and simulations in determining the Z-blade effectiveness was discussed in this section. While there were small differences in performance across various experiments, these variations were observed to cancel each other out, thus resulting in a consistent outcome across all experiments. While accounting for kinetic energy and fluid friction losses, the conceptual structural properties were expected using the mathematical equation. In Figure 4, the results of Z-Blade turbine vary between $0.3 \mathrm{~m}$ and $2.0 \mathrm{~m}$ for the rotor radius, and the PVC pipe's nominal diameter is $25 \mathrm{~mm}$ (1").

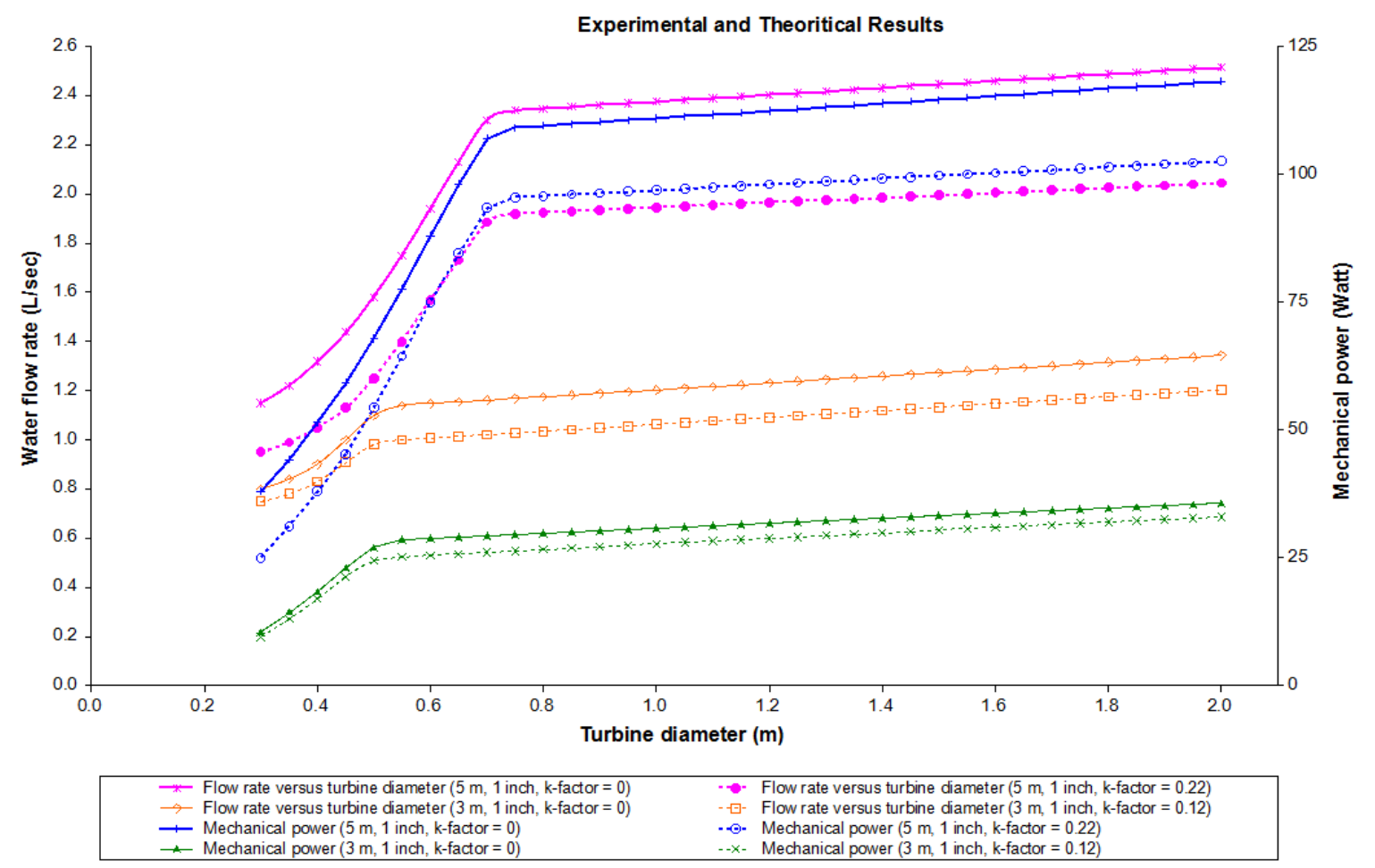

Fig. 4. Mass flow rate and mechanical power vs turbine width 
Figure 4 depicts flowrate and power mechanical at various water heads, illustrating the magnitude of mass flow rate and mechanical power. This figure illustrates a conceptual power curve, which represented different turbine diameters at $3 \mathrm{~m}$ and $5 \mathrm{~m}$ water heads. Surprisingly, output power vs mass flow rate graph is directly proportional to one another. There is a significant increase in the mass flow rate at a moment where the water flow decreases from higher to lower. At that stage, the level of power output increases begins to decrease sharply. An extremely high head generally results in a shift to the right on the graph. The turbine width (highest achieving) tends to increase as the operating head increases. The theoretical results of mechanical power are computed using Eq. (6) and (7), as the product of mass flow rate, rotor diameter, absolute velocity and rotational speed. This research shows that experimental and analytical results also agree, which means that the results found in the lab are accurate. More or less, the turbine performance increases at a water head of $5 \mathrm{~m}$, but decreases at $3 \mathrm{~m}$.

Water head causes an increase of the angular velocity surge, which results in an increase in power output. Measuring the mechanical output power for a $5 \mathrm{~m}$ pressure and comparing it to the energy produced at a $3 \mathrm{~m}$ water head demonstrates that the mechanical power output is higher. Intended for best results, the Z-Blade turbine should be used at a distance of $5 \mathrm{~m}$, in order to generate 100 $\mathrm{kg} / \mathrm{m}^{2} \mathrm{~s}^{-3}$ of mechanical power. The experimental and theoretical results also show close outcomes, which indicates that the experimental results are indeed reliable.

Figure 5 shows the efficiency curves of SRT, CPT and ZBT adapted from Date [7]. It can be seen that the efficiency of these reaction turbines approaching each other at low rotational speed. However, at higher rotational speed, the estimated efficiency curves are further away. The maximum efficiency of ZBT is $78 \%$, followed by SRT at $62 \%$ and finally CPT at $53 \%$. It is clearly shows that ZBT operates efficiently compared to SRT and CPT at the same rotational speed.

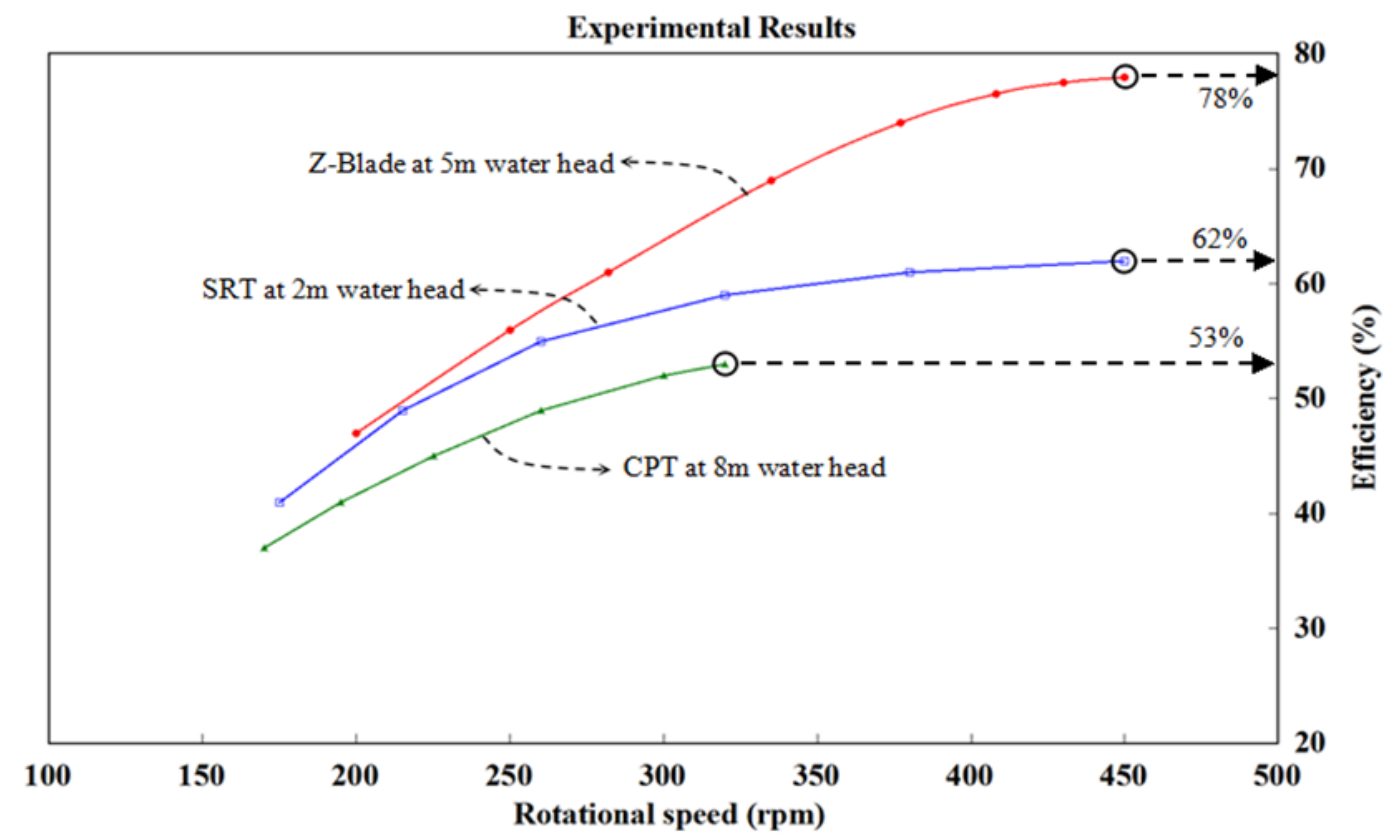

Fig. 5. Efficiency curves for SRT, CPT and ZBT

\section{Conclusions}

This study concluded that the Z-Blade turbine, a reconfigured framework developed from the CPT and SRT, had various benefits. This system introduces the most inexpensive and the simplest picohydro generation system, where small streams are good enough to operate efficiently. Since it is 
created utilising commonly accessible regular components, such as normal water piping and PVC pipe fittings, the project is simple to make, and minimal costs are required to do so. The total expenses for fabricated the system was only USD76 and capable producing $115 \mathrm{~W}$ output power which able to provide a single household in rural area. Since the new design in this manuscript has the prospects to be used in a pico-hydro scheme, especially for low and low-flow water resources, the system presented in this article is a reaction-type rotor.

\section{Acknowledgement}

The authors would like to thank the Ministry of Higher Education, Malaysia for funding this research (MTUNC/2019/FTKEE-CERIA/MC0013), Universiti Teknikal Malaysia Melaka (UTeM) and Universiti Kebangsaan Malaysia (UKM) for providing the laboratory accommodations and technical support.

\section{References}

[1] Rais, Nurul Ashikin Mohd, and M. F. Basar. "Pico-Hydro Generation System: Empirical Investigation on a Novel ZBlade Low-Head Low-Flow Water Turbine." International Journal of Renewable Energy Research (IJRER) 11, no. 1 (2021): 108-113.

[2] Basar, Mohd Farriz, Fatin Syakira Mohd Hassan, Nurul Ashikin Rais, Izzatie Akmal Zulkarnain, and Wan Azani Wan Mustafa. "Performance Analysis of Z-Blade Reaction Type Turbine for Low-Head Low Flowrate Pico Hydro." Journal of Advanced Research in Fluid Mechanics and Thermal Sciences 85, no. 2 (2021): 51-65. https://doi.org/10.37934/arfmts.85.2.5165

[3] Çelo, Marialis, and R. Bualoti. "Grid Integration Issues and Possible Solutions Considering the Expansion and Deployment of Hydropower Plants in Albania." International Review of Electrical Engineering (IREE) 15, no. 1 (2020): 80. https://doi.org/10.15866/iree.v15i1.16497

[4] Ebhota, W. S., and P. Y. Tabakov. "The Development of Civil Components of a Small Hydropower System." International Review of Civil Engineering (IRECE) 10, no. 6 (2019): 274. https://doi.org/10.15866/irece.v10i6.16261

[5] Yaakub, M. Faizal, M. Farriz Basar, F. Hanim Mohd Noh, and Hambali Boejang. "Pico-hydro Electrification from Rainwater's Gravitational Force for Urban Area." Telkomnika 16, no. 3 (2018): 997-1003. https://doi.org/10.12928/telkomnika.v16i3.8076

[6] Basar, Mohd Farriz, Fatin Syakira Mohd Hassan, Nurul Ashikin Rais, Izzatie Akmal Zulkarnain, and Wan Azani Wan Mustafa. "Performance Analysis of Z-Blade Reaction Type Turbine for Low-Head Low Flowrate Pico Hydro." Journal of Advanced Research in Fluid Mechanics and Thermal Sciences 85, no. 2 (2021): 51-65. https://doi.org/10.37934/arfmts.85.2.5165

[7] Date, A. "Low head simple reaction water turbine." School of Aerospace Mechanical and Manufacturing Engineering. RMIT University (2009).

[8] Date, Abhijit, and Aliakbar Akbarzadeh. "Design and cost analysis of low head simple reaction hydro turbine for remote area power supply." Renewable Energy 34, no. $2 \quad$ (2009): $409-415$. https://doi.org/10.1016/i.renene.2008.05.012

[9] Date, Abhijit, Aliakbar Akbarzadeh, and Ashwin Date. "Performance investigation of a simple reaction water turbine for power generation from low head micro hydro resources." Smart Grid and Renewable Energy 3, no. 03 (2012): 239. https://doi.org/10.4236/sgre.2012.33033

[10] Date, Abhijit, Ashwin Date, and Aliakbar Akbarzadeh. "Investigating the potential for using a simple water reaction turbine for power production from low head hydro resources." Energy Conversion and Management 66 (2013): 257-270. https://doi.org/10.1016/j.enconman.2012.09.032

[11] Akbarzadeh A, Dixon C, JohnsonP. "Parametric analysis of a simple reaction water turbine and its application for power production from low head reservoirs." In Fluids engineering division summer meeting. New Orleans, Louisiana, USA: ASME; (2001)

[12] Dadfar, A., M. Besharat, and H. M. Ramos. "Storage ponds application for flood control, hydropower generation and water supply." International Review of Civil Engineering (IRECE) 10, no. 4 (2019): 219-226. https://doi.org/10.15866/irece.v10i4.17133

[13] Towoju, Olumide Adewole, and Felix Adedayo Ishola. "Pros and Cons of Electricity Generation from Different Available Sources." (2020). https://doi.org/10.15866/ireme.v14i6.19104

[14] Kadier, Abudukeremu, Mohd Sahaid Kalil, Manoj Pudukudy, Hassimi Abu Hasan, Azah Mohamed, and Aidil Abdul Hamid. "Pico hydropower (PHP) development in Malaysia: Potential, present status, barriers and future 
perspectives." Renewable and Sustainable Energy Reviews $81 \quad$ (2018): 2796-2805. https://doi.org/10.1016/i.rser.2017.06.084

[15] Safdar, Ibadullah, Sara Sultan, Hamza Ahmad Raza, Muhammad Umer, and Majid Ali. "Empirical analysis of turbine and generator efficiency of a pico hydro system." Sustainable Energy Technologies and Assessments 37 (2020): 100605. https://doi.org/10.1016/j.seta.2019.100605

[16] Kirke, Brian. "Hydrokinetic and ultra-low head turbines in rivers: A reality check." Energy for Sustainable Development 52 (2019): 1-10. https://doi.org/10.1016/i.esd.2019.06.002

[17] Adanta, Dendy, Budiarso Budiarso, and Ahmad Indra Siswantara. "Assessment of turbulence modelling for numerical simulations into pico hydro turbine." Journal of Advanced Research in Fluid Mechanics and Thermal Sciences 46, no. 1 (2018): 21-31.

[18] Towoju, Olumide Adewole, and Felix Adedayo Ishola. "Pros and Cons of Electricity Generation from Different Available Sources." International Review of Mechanical Engineering (IREME) 14, no. 6 (2020): 374. https://doi.org/10.15866/ireme.v14i6.19104

[19] Adanta, Dendy, Warjito Warjito, Dwijaya Febriansyah, and Budiarso Budiarso. "Feasibility Analysis of a Pico-Scale Turgo Turbine Bucket using Coconut Shell Spoons for Electricity Generation in Remote Areas in Indonesia." Journal of Advanced Research in Fluid Mechanics and Thermal Sciences 69, no. 1 (2020): 85-97. https://doi.org/10.37934/arfmts.69.1.8597

[20] Febriansyah, Dwijaya, Budiarso Budiarso, Warjito Warjito, Keizo Watanabe, and Dendy Adanta. "Storage system manufacturability, portability and modularity for a pico hydro turbine." Journal of Advanced Research in Fluid Mechanics and Thermal Sciences 51, no. 2 (2018): 209-214. 